\title{
The Australian woman movement, 1880-1914: Sexuality, marriage and consent
}

\author{
REBECCA PRESTON
}

\section{Abstract}

The Australian woman movement (1880-1914) played a central role in shaping contemporary sexual discourse and contributing to the eventual recognition of female sexual pleasure in Australia. While most historiography has focused on the more well-known suffrage campaigns, this essay explores feminist attempts to enhance women's sexual autonomy through reforming existing sexual relations, particularly in marriage, and contesting contemporary medical discourse which defined male sexuality as 'hydraulic', namely automatically aroused, and female sexuality as 'hysterical'. The early Australian feminists publicly challenged Victorian constructions of sexuality and sought to redefine male-female sexual relations by abolishing the double standard of sexual morality. Studying the woman movement through the lens of sexuality is important, as issues of sexuality were inextricably linked to more wellknown political and economic campaigns for suffrage, citizenship and equal pay. Feminist campaigns to reform sexuality in both the public and private spheres were also central to broader political debates concerning the health and future of Australia's population, and the declining birth and marriage rate. A study of feminist campaigns to reform domestic sexual relations, primarily through enhancing women's autonomy in the marital bedroom, and campaigns to improve public sexual relations through regulating prostitution, raising the age of consent and reducing the occurrence of venereal disease through education, reveals the complex interactions between various sectors of colonial society, including feminist organisations, the medical profession, the Australian government, the military and religious groups. As such, this study provides a more nuanced understanding of late nineteenth- and early twentieth-century Australian political and social life. 
Concerns about male and female sexuality were fundamental to the central ideas and campaigns of the woman movement in Australia between 1880 and $1914 .{ }^{1}$ The woman movement encompassed the ideas of prominent women activists and the activities of women's clubs, literary associations, temperance societies and suffrage leagues. The movement primarily aimed to achieve suffrage for women as a means to ameliorating their legal, economic and sexual inequality. Although leading activists were politically diverse, they shared a collective consciousness derived from a sense of passion for women's enfranchisement and freedom from sexual degradation and exploitation. Due to the high marriage and birth rates in Australia, the woman movement subscribed to the 'separate spheres doctrine', primarily focusing on protecting married women in the private, domestic sphere. ${ }^{2}$ This essay will demonstrate the paramount significance of sexuality to the woman movement by assessing two central campaigns - reform of the condition of marriage and raising the age of consent. Both campaigns centred on changing the sexual double standards applied to men and women, which feminists believed were the causes of female sexual degradation and male sexual excess and immorality. This essay seeks to highlight the ways in which early feminists challenged contemporary articulations of male and female sexuality.

The importance of the woman movement to Australian feminist history has frequently been overlooked by twentieth-century historians. Feminist historian Anne Summers popularised the view that early feminists were 'God's Police'. These women, according to Summers, 'discourage[d] women from enjoying their sexuality' and advocated for the 'Victorian characterisation of women as pure and noble $\ldots$ and as needing special protection'. ${ }^{3}$ Summers concluded that early feminists failed to 'provide a radical alternative vision for women' as they extolled women's maternal role and did not 'delve more deeply into the causes of women's oppression' or 'examine the differing aspirations of women themselves' . Despite the sometimes dismissive approach towards the achievements of suffrage women, feminist historians have made important historiographical contributions through exploring issues of sexuality in relation to the woman movement. Historians such as Judith Allen, Marilyn Lake and Susan Magarey analyse the ways in which early feminists challenged the 'masculinist national culture' of Australia by redefining contemporary understandings of male and female sexuality. ${ }^{5}$

\footnotetext{
1 This thesis uses the expression 'woman movement' because this was the phrase adopted by leading feminists in the late nineteenth and early twentieth centuries. See e.g. Women's Political Association, The Life and Work of Miss Vida Goldstein (Melbourne: Australasian Authors' Agency, 1913).

2 Katie Spearritt, 'New Dawns: First Wave Feminism 1880-1914', in Gender Relations in Australia: Domination and Negotiation ed. Kay Saunders and Raymond Evans, (Sydney: Harcourt Brace Jovanovich, 1992), 339.

3 Anne Summers, Damned Whores and God's Police (Ringwood, Victoria: Penguin Books, 1994), 419. Ibid.

Frank Bongiorno, "'Every Woman A Mother": Radical Intellectuals, Sex Reform and the "Woman Question" in Australia, 1890-1918', Hecate 27:1 (2001): 44; see Judith Allen, “'Our Deeply Degraded Sex" and “The Animal in Man": Rose Scott, Feminism and Sexuality 1890-1925', Australian Feminist Studies 7 \& 8. (Summer 1988), 65-91; Marilyn Lake, Getting Equal: The History of Australian Feminism (Sydney: Allen \& Unwin, 1999); Susan Magarey, Passions of the First Wave Feminists (Sydney: University of New South Wales, 2001).
} 
In the late nineteenth century, Australia was an 'intellectual ferment' of radical political ideologies, including nationalism and socialism. ${ }^{6}$ The growth in employment and educational opportunities for women led to the emergence of intellectual middle-class women and an urban bourgeoisie. ${ }^{7}$ It was in this context that the woman movement emerged, challenging Victorian gender roles and ideals of male and female sexuality. The woman movement developed independently in each state and territory, particularly flourishing in the urban centres of Sydney, Melbourne and Adelaide. Feminist ideas circulated through public discourse, parliamentary petitions, various societies and organisations and feminist newspapers and journals, such as The Dawn and Woman's Voice. These feminist journals will be examined to shed light on the opinions and ideas of leading activists and their motivations for particular campaigns.

The campaign for women's suffrage and citizenship was inextricably linked to reforms to alter women's position as degraded sex slaves. Women activists focused their campaign for sexual reform on married women, as wives epitomised the sexual exploitation and degradation of women. Marriage reflected the double standards of morality and sexuality between the sexes. Women who were trapped in loveless marriages were viewed as victims of the coercive exercise of husbandly conjugal rights, which resulted in further oppression from bearing and rearing large families. ${ }^{8}$ Feminists such as Rose Scott, Louisa Lawson and Ada Cambridge believed that married women sacrificed their bodies and independence to satisfy their husband's sexual desires and conform to ideals of respectability and social status. ${ }^{9}$ In The Dawn, Lawson argued that the 'marriage career' resulted in the 'abandonment of individuality' and the wife was 'expected to endure nightly' her fate in the 'chamber of horrors' ${ }^{10}$ This theme of sexual exploitation in the marital bedroom is similarly expressed in Ada Cambridge's poetry. In her poem, A Wife's Protest, Cambridge emotively depicts the 'creeping terrors' of 'each black night' - 'I lay me down upon my bed / A prisoner on the rack / And suffer dumbly, as I must'. ${ }^{11}$ Cambridge described the feminist concern of enforced maternity, later termed marital rape. ${ }^{12}$

Women activists sought to improve women's ability to negotiate marital sex by reforming male sexuality and advocating women's sexual autonomy manifested in their right to voluntary motherhood. Sexual coercion in marriage was viewed as a result of uncontrollable male sexuality, combined with women's

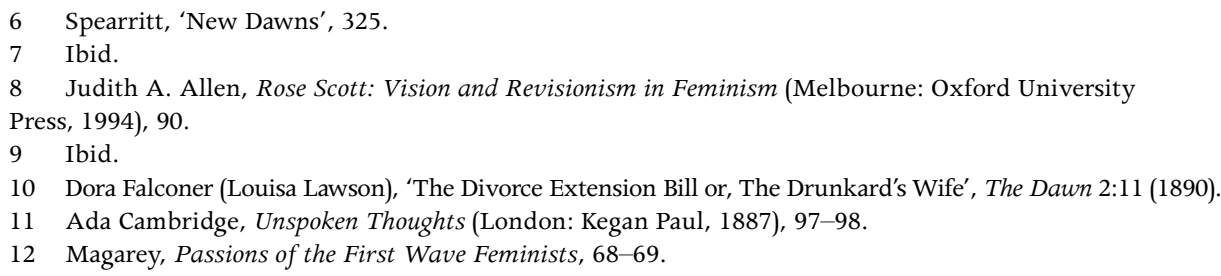


endurance of men's 'selfish animalism' without resistance. ${ }^{13}$ Echoing Victorian ideals, male sexuality in the late nineteenth and early twentieth centuries was depicted as helplessly 'hydraulic' - men were at the mercy of their natural urges. ${ }^{14}$ The woman movement challenged the idea that male sexuality was hydraulic by urging mothers to educate their sons in a manner which would abolish sexual double standards. Mothers were to educate their sons to control 'the most dangerous instinct of his animal nature' and 'show him ... the dire physical effects of excessive indulgence in this passion' ${ }^{15}$ In conjunction with reforming male sexuality, early feminists believed women could use self-help to improve their marital position by being 'selfish for the cause of progress' ${ }^{16}$ Lawson encouraged women to enhance their 'individualism' and 'have more dignity', 'worth', 'liberty' and 'respect', so that 'there will be no need to change the method of marriage relationships' as women will be 'a better treated class'. ${ }^{17}$ Through educating the moral consciousness of society and changing attitudes towards male and female sexuality, early feminists hoped that women would gain sexual autonomy and be placed in a privileged position in marriage. ${ }^{18}$

In order to change the condition of marriage, women activists advocated various reforms, including contraception, sexual restraint, abstinence and marriage based on love. Marriage based on love was advocated by most feminists as a necessary means to altering the position of women in marriage and reforming attitudes towards marital sex. Support for other solutions, particularly contraception, was divided as many women, such as Maybanke Wolstenholme and Scott, believed that such measures did not change the fundamental issue of women being used as sexual property by men. Love, however, was widely accepted as part of the solution to a happy marriage. Lawson argued that 'marrying for wealth, position, or any consideration other than love' was the primary reason for 'matrimonial infelicities'. ${ }^{19}$ She noted, however, that 'love matches' can be 'equally unhappy' and 'perfect confidence and absolute truthfulness' are necessary in addition to love. ${ }^{20}$ Agnes Benham similarly promoted love as 'the universal redeemer' ${ }^{21}$ She argued that 'love, not marriage, sanctifies the act of procreation' ${ }^{22}$ The idea that sex, especially marital sex, should be based on love is similarly explored in Cambridge's poem Fallen:

13 Rose Scott, quoted in Allen, Rose Scott, 90.

14 Magarey, Passions of the First Wave Feminists, 91.

15 Ohara, 'The Problems of the Streets', The Woman's Voice 1:5 (1894), 66.

16 Dora Falconer (Louisa Lawson), 'The Legal Link', The Dawn 3:3 (1890).

17 Ibid

18 Allen, 'Our Deeply Degraded Sex',71.

19 Dora Falconer (Louisa Lawson), 'Unhappy Love Matches', The Dawn 2:2 (1889).

20 Falconer, 'Unhappy Love Matches'.

21 Agnes Benham, Love's Way to Perfect Humanhood: An Appeal to Thoughtful People (Adelaide: The Century Printer, 1904), 37.

22 Ibid., 38. 
... She who, for vulgar gain

And in cold blood, and not for love or need,

Has sold her body to more vile disgrace -

... Wife by the law, but prostitute in deed,

In whose gross wedlock womanhood is slain..$^{23}$

Cambridge stressed the idea that marital sex was analogous to the sexual contract between a female prostitute and her male client; as such a contract was loveless and based on satisfying male sexual desires. Cambridge extended this idea further in her poem $A$ Wife's Protest, suggesting that if 'my ragged sister of the street ... gave her all for love ... her crown of womanhood was not ignobly lost' ${ }^{24}$ She depicted women prostitutes as 'pure', admiring their ability 'to keep her body for her own' ${ }^{25}$ Rose Scott held a more sceptical view of love as a basis for sex and marriage. She believed that men's love for women was merely 'the indulgence of an animal passion' ${ }^{26}$ She advocated sexual abstinence as the only solution to protect women from the sexual slavery of marriage and the dangers of pregnancy and childbirth. The Woman's Voice - a feminist journal founded by Wolstenholme - also cautioned women against 'free-love' as an alternative to feminist attempts to 'alter the marriage customs' ${ }^{27}$ Reforming the condition of marriage was at the forefront of the woman movement as it was a microcosmic reflection of male exploitation of women in the public sphere, namely through prostitution and the seduction of young girls.

As well as shifting attitudes towards marital sex, the woman movement campaigned for legal reform to protect the sexual exploitation of young girls. The seduction and abandonment of young girls by older men reinforced the belief that hydraulic male sexuality was a primary cause of women's oppression. This moral panic about the brutal effects of uncontrollable male sexuality, especially among the male youth, was reaffirmed in the aftermath of the Mount Rennie case in 1886. The case involved the conviction of nine young men, four of which were publicly hung, for raping 16-year-old Mary Jane Hicks. ${ }^{28}$ The woman movement was animated by a profound sense of feminine vulnerability and anxiety about unrestrained masculine sexuality. This protection-centred approach was a product of contemporary dangers associated with sex. Such dangers included venereal disease, the social shame of illegitimate children, sexual violence inflicted by drunken men and the severe health risks of pregnancy and childbirth. ${ }^{29}$ To protect young girls from sexual exploitation and

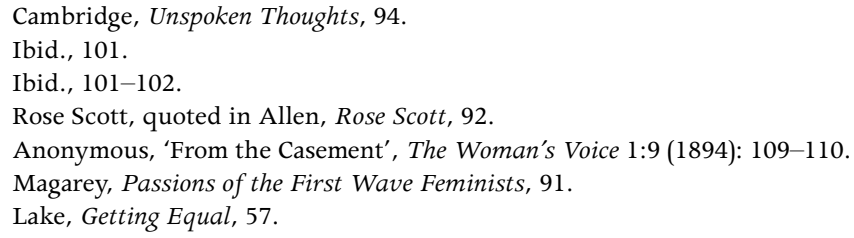


subsequent prostitution, women activists campaigned to legally raise the age of consent to 17 in New South Wales and 21 in Victoria. ${ }^{30}$ As president of the Women's Political Education League, Scott was actively involved in the age of consent campaign in New South Wales. Scott petitioned to increase support for the Vice Suppression Bill, tabled in 1892 by J. C. Nield. The objectives of the bill 'were chiefly the protection of youth, and the suppression of establishments of a notoriously immoral character' ${ }^{31}$ The Bill proposed to criminalise seduction with the promise of marriage and raise the age of consent of girls from 14 to 16 years of age. The aims of the 1892 Bill were ultimately implemented in the Crimes (Girls' Protection) Act 1910, raising the age of consent to 16 years and making it illegal for brothels to employ girls under the age of 18 years. ${ }^{32}$

The age of consent campaign was particularly contentious, receiving divided support within the woman movement. Raising the age of consent was premised on the fact that men were the seducers and primarily responsible for the demise of young women and subsequent illegitimate children. This assumption fundamentally challenged the depiction of male sexuality as hydraulic, as extramarital sex and/or the seduction of young women was not deemed natural, necessary or inevitable. ${ }^{33}$ By redefining male sexuality, the age of consent campaign sparked significant confrontation over sexual mores and power. This led to divided support among suffrage women, as many were unwilling to blatantly undermine male sexual dominance or shift responsibility for illegitimate children to men. ${ }^{34}$ Several male parliamentarians had similar objections to raising the age of consent. Mr Philip Henry Morton, a member of the Vice Suppression Bill Committee, feared that such legislative reform would 'interfere with [male] liberty' and improvements would be more effective through 'the gradual development of the moral sense of the people'. ${ }^{35}$ The age of consent campaign also served to diminish sexual double standards. Scott objected to the categorisation of women according to male sexuality. In particular, she criticised the idealisation of virtuous women and the ostracism of fallen women, as the latter category was the result of men's sexual indiscretion. In an unpublished speech, Scott described men as occupying the 'pulpits' while preaching 'righteousness' ${ }^{36}$ In addition to legislative reform, feminists encouraged mothers to educate their sons to avoid premarital sex, particularly with young women. According to The Woman's Voice, mothers needed to fulfil this educative duty to 'acquit herself of all blame' for 'her fallen sister' ${ }^{37}$ The Woman's Voice

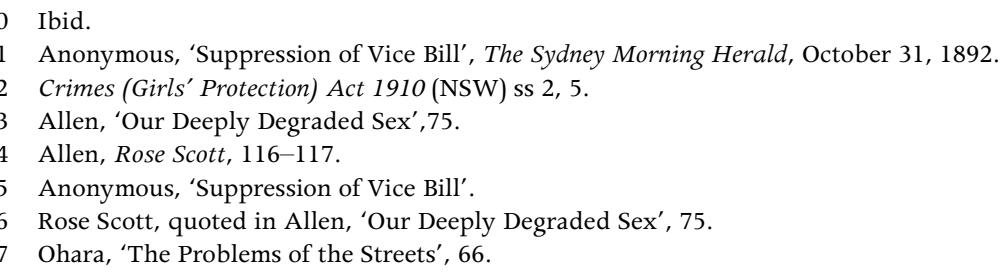


promoted the idea of universal sisterhood, whereby mothers were to take moral responsibility for the protection of vulnerable women, including young girls and prostitutes.

\section{Conclusion}

Male and female sexuality was a primary concern of the woman movement, as contemporary articulations of sexuality formed the ideological basis of early feminist campaigns. The woman movement ultimately sought freedom from masculine power and the unrestrained exercise of male sexual passions. Women activists campaigned to end female sexual degradation in both the private sphere, through reforming the condition of marriage, and the public sphere, by raising the age of consent. Feminists prioritised changing the moral consciousness of society by challenging hydraulic male sexuality and encouraging women to shed 'the yoke of servitude' by asserting independence over their 'soul and flesh'. ${ }^{38}$ Although reforming male sexuality was a primary concern, women activists similarly encouraged women to control their own sexuality through marrying for love, educating their sons that 'the degradation of a woman is his own degradation' and/or abstaining from sex. ${ }^{39}$ The principle concerns of the woman movement centred on sexuality and played an important role in advancing female autonomy and improving legal protection for women.

\section{Bibliography}

\section{Primary}

Anonymous. 'From the Casement'. The Woman's Voice 1:9 (1894): 109-110.

'Suppression of Vice Bill'. The Sydney Morning Herald. October 31, 1892.

Benham, Agnes Nesbit. Love's Way to Perfect Humanhood: An Appeal to Thoughtful People. Adelaide: The Century Printer, 1904.

Cambridge, Ada. Unspoken Thoughts. London: Kegan Paul, 1887.

Crimes (Girls' Protection) Act 1910 (NSW).

Falconer, Dora (Louisa Lawson). 'The Divorce Extension Bill or, The Drunkard's Wife'. The Dawn 2:11 (1890).

38 Cambridge, Unspoken Thoughts, 142

39 Ohara, 'The Problems of the Streets', 66. 
—. 'The Legal Link'. The Dawn 3:3 (1890).

—. 'Unhappy Love Matches'. The Dawn 2:2 (1889).

Ohara, 'The Problems of the Streets'. The Woman's Voice 1:5 (1894): 66.

Women's Political Association, The Life and Work of Miss Vida Goldstein. Melbourne: Australasian Authors' Agency, 1913.

\section{Secondary}

Allen, Judith A. "Our Deeply Degraded Sex" and "The Animal in Man": Rose Scott, Feminism and Sexuality 1890-1925'. Australian Feminist Studies 7 \& 8 (Summer 1988): 65-91.

. Rose Scott: Vision and Revisionism in Feminism. Melbourne: Oxford University Press, 1994.

Bongiorno, Frank. "Every Woman A Mother": Radical Intellectuals, Sex Reform and the "Woman Question" in Australia, 1890-1918'. Hecate 27:1 (2001): 44-64.

Lake, Marilyn. Getting Equal: The History of Australian Feminism. Sydney: Allen \& Unwin, 1999.

Magarey, Susan. Passions of the First Wave Feminists. Sydney: University of New South Wales, 2001.

Spearritt, Katie. 'New Dawns: First Wave Feminism 1880-1914'. In Gender Relations in Australia: Domination and Negotiation, edited by Kay Saunders and Raymond Evans, 325-349. Sydney: Harcourt Brace Jovanovich, 1992.

Summers, Anne. Damned Whores and God's Police. Ringwood, Victoria: Penguin Books, 1994. 
This text is taken from The ANU Undergraduate Research Journal, Volume Six, 2014, edited by Jonathon Zapasnik and Alexandra Hogan, published 2015 by ANU eView, The Australian National University, Canberra, Australia. 